\title{
ANALISIS PANEL ATAS PENGARUH EKONOMI DAN SOSIAL MASYARAKAT TERHADAP KEMANDIRIAN FISKAL PEMERINTAH KABUPATEN/KOTA DI SULAWESI UTARA
}

\author{
Herman Karamoy dan Agus Tony Poputra
}

Email : hkaramoy@yahoo.com

\begin{abstract}
This paper analyzes the impact of economic and social variables on fiscal independence of district government in Province of North Sulawesi. Scope of research includes all districts in 2009-2012. To analyze secondary data, we utilize the Pooled EGLS (Cross-section random effects) method. This research not only use secondary data, but also primary data. The primary data are used to get deep picture about factors that lower fiscal dependence of districts in North Sulawesi. Those data are collected by interview to parties related to generate own resource revenues and by focus discussion group with academicians. This research finds that economic development and population in districts of North Sulawesi do not affect on fiscal independence. Otherwise, only variable human development index has significantly positive effect on fiscal independence. These findings are supported by primary data which show that: (1) most activities of dominant economic factor of those districts, except Manado and Bitung, namely agriculture, are not tax or surcharge objects; (2) types of local government tax have small tax base for districts and varies between dictricts that have big cities and small cities; (3) low of human resource capacity and creativity to generate own source revenues effectively and efficiently; and (4) low of taxpayers compliance.

Keywords: fiscal independence, economic development, human development index, population.
\end{abstract}

\section{Pendahuluan}

Otonomi daerah di Indonesia efektif dimulai pada tahun 2001. Dasar hukum otonomi daerah tersebut adalah Undang-Undang (UU) Nomor 22 Tahun 2009 tentang "Pemerintah Daerah" yang disertai dengan UU Nomor 25 Tahun 2009 tentang "Perimbangan Keuangan antara Pemerintah Pusat dan Daerah" yang menjadi konsekuensi otonomi daerah. Dalam perjalanannya, kedua UU tersebut mengalami revisi menjadi UU Nomor 32 Tahun 2004 dan UU Nomor 33 tahun 2004, berturut-turut. Otonomi daerah yang diterapkan di Indonesia adalah pemberian otonomi langsung kepada pemerintah kabupaten/kota dimana provinsi hanya perpanjangan tangan dari pemerintah pusat. Cara ini berbeda dengan sistem otonomi yang diterapkan oleh beberapa negara lain, seperti Amerika Serikat, dimana pemerintah pusat memberi otonomi kepada pemerintah provinsi (negara bagian) dan selanjutnya provinsi memberikan otonomi kepada kabupaten/kota.

Saat ini, kedua UU di atas juga sedang dalam proses revisi untuk mendapatkan suatu pola yang sesuai mengingat perubahan lingkungan yang terjadi serta banyak permasalahan yang timbul dalam pelaksanaan otonomi sehingga mengaburkan misi dari otonomi daerah. Menurut Mardiasmo (2002:59), terdapat tiga misi utama dalam otonomi daerah, yaitu sebagai berikut.

1. Menciptakan efisiensi dan efektivitas pengelolaan sumber daya daerah.

2. Meningkatkan kualitas pelayanan umum dan kesejahteraan masyarakat.

3. Memberdayakan dan menciptakan ruang bagi masyarakat untuk ikut serta (berpartisipasi) dalam proses pembangunan. 
Pelaksanaan desentralisasi fiskal yang merupakan konsekuensi dari otonomi daerah pada hakikatnya memuat harapan terciptanya pembangunan dari bawah (Bahl, 1999:2). Dalam konteks ekonomi, Oates (1993) menyatakan bahwa "desentralisasi fiskal dimaksudkan untuk meningkatkan efisiensi ekonomi dimana penyediaan barang dan jasa publik dapat berbeda-beda disesuaikan dengan selera dan kondisi masing-masing daerah sehingga dapat memberikan kesejahteraan sosial yang lebih besar ketimbang penyediaan barang dan jasa publik ditentukan secara sentralistik dan dengan jumlah yang sama lintas jurisdiksi."

Otonomi daerah dan desentralisasi fiskal merupakan penyerahan kewenangan dari pemerintah pusat ke daerah otonomi yang disertai dengan penyerahan sumber-sumber pembiayaannya (money follows function). Oates (2005) menekankan pada pentingnya ketergantungan pada Pendapatan Asli Daerah (PAD) dalam membiayai anggaran daerah. Hal ini terkait dengan penerapan anggaran ketat, yang menegaskan akan bahaya dalam suatu sistem jika pemerintah daerah otonom sangat tergantung pada transfer pemerintah di atasnya untuk membiayai anggaran mereka. Selanjutnya, Lovell (1981:197) memperlihatkan bahwa semakin tinggi tingkat ketergantungan daerah otonom terhadap transfer pemerintah pusat akan menyebabkan semakin tingginya ketergantungan kebijakan (policy dependency) pemerintah daerah otonom terhadap pemerintah pusat. Ketergantungan kebijakan mencakup tanggung jawab, prosedur, atau kegiatan yang dibebankan oleh suatu tingkatan pemerintah kepada tingkatan pemerintah lainnya lewat konstitusi, legislatif, eksekutif, atau tindakan yudisial yang merupakan perintah langsung ataupun sebagai persyaratan bantuan.

Adanya ketergantungan kebijakan yang tinggi dari pemerintah daerah otonom kepada pemerintah di atasnya jika daerah tersebut memiliki ketergantungan fiskal yang tinggi, maka pemerintah daerah perlu memperbesar PAD mereka. Kemampuan untuk menghasilkan PAD tergantung pada beberapa faktor diantaranya sebagai berikut.

1. Potensi pendapatan yang dapat diperoleh dari sumber-sumber pembiayaan yang diserahkan pemerintah pusat kepada pemerintah daerah, termasuk kekuatan pemajakan (taxing power).

2. Kemampuan pemerintah daerah untuk mengumpulkan PAD, termasuk kemampuan melakukan pengawasan untuk menghindari kebocoran pendapatan.

3. Kemampuan ekonomi suatu daerah

4. Kondisi sosial masyarakat

Sumber-sumber pendapatan yang diserahkan oleh pemerintah pusat kepada daerah otonom seringkali menimbulkan masalah. Masalah utama yang ada, yaitu kebanyakan sumber penerimaan, khususnya pajak daerah memiliki basis yang sempit (narrow tax base) sehingga menyulitkan pemerintah daerah menghasilkan pendapatan memadai lewat sumber-sumber penerimaan tersebut. Masalah tersebut ditemukan oleh beberapa peneliti di dunia diantaranya oleh Salazar dan Guajardo (2009). Penelitian mereka menemukan bahwa sejak pemerintah Meksiko menerapkan National Sistem of Fiscal Coordination (NSFC) untuk menghindari tumpang tindih pajak atas objek yang sama antara pemerintah pusat dan daerah dengan menerapkan bagi hasil, telah meningkatkan ketergantungan pemerintah daerah terhadap bagi hasil dari pemerintah pusat.

Walaupun pemerintah daerah mendapatkan pelimpahan sumber pembiayaan yang berbasis luas, namun sering pemerintah daerah tidak dapat menghasilkan PAD yang semestinya. Kondisi ini dapat disebabkan oleh kelemahan sumber daya manusia dari aparatur pemerintah daerah, strategi pemerintah daerah untuk memperoleh dana ekualisasi yang besar dari pemerintah pusat, kebocoran dalam pemungutan, atau lain sebagainya. 
Selain dari sisi internal pemerintah, kondisi perekonomian suatu daerah yang mencakup besaran dan pertumbuhannya dapat mempengaruhi kemampuan pemerintah daerah dalam menghasilkan PAD (Utami, 2012; Hidayat, 2009). Suatu daerah otonomi yang memiliki perekonomian yang besar dapat memperoleh subjek dan objek pajak dan retribusi daerah yang besar yang memampukan mereka memperoleh PAD yang lebih besar. Sebaliknya, bagi daerah yang perekonomiannya terbatas akan kesulitan memperoleh PAD yang besar. Oleh sebab itu, dalam pembentukan suatu daerah otonomi baru, potensi ekonomi menjadi salah satu persyaratan penting. Namun demikian, sering faktor ekonomi dikalahkan oleh kepentingan politik sehingga banyak daerah otonom baru yang tidak layak secara ekonomi tetap dipaksakan dibentuk karena didasarkan pada pertimbangan politik yang akhirnya membuat daerah otonom baru memiliki ketergantungan yang tinggi terhadap pemerintah pusat.

Faktor eksternal lain yang dapat mempengaruhi PAD seperti dikemukakan di atas adalah kondisi sosial masyarakat. Semakin baik kondisi sosial masyarakat suatu daerah maka pendapatan yang diperoleh masyarakat semakin besar. Dengan pendapatan yang semakin besar, maka masyarakat dapat melakukan konsumsi yang lebih besar pula sehingga pada gilirannya akan memperbesar basis pajak maupun retribusi daerah.

Dengan semakin mampunya pemerintah daerah menghasilkan PAD, maka semakin tinggi kemandirian fiskal. Kondisi ini merupakan kondisi yang diharapkan dalam otonomi dan desentralisasi fiskal. Kemandirian yang tinggi membuat pemerintah daerah dapat menyediakan barang dan jasa bagi masyarakat sesuai dengan karakteristik daerahnya, tidak terlalu tergantung kepada kebijakan pusat yang umumnya seragam antar daerah otonom.

Penerapan otonomi dan desentralisasi fiskal di Indonesia telah berjalan hampir 15 tahun. Namun demikian, ketimpangan antar daerah (horizontal imbalances) masih terjadi terutama antara daerah yang memiliki sumber daya alam yang besar dengan daerah yang memang miskin sumber daya alam. Oleh sebab itu, pemerintah pusat masih tetap memberikan transfer dalam jumlah besar kepada pemerintah daerah dalam bentuk Dana Alokasi Umum (DAU) yang besarnya sekurang-kurangnya 25 persen dari penerimaan dalam negeri yang ditetapkan dalam APBN, serta berbagai jenis transfer lainnya.

Berdasarkan uraian di atas penelitian ini mengkaji mengenai pengaruh faktor ekonomi yang diproksi oleh Produk Domestik Regional Bruto (PDRB) dan faktor sosial yang diproksi oleh Indeks Pembangunan Manusia dan Jumlah Populasi, dengan objek penelitian pemerintah kabupaten/kota di Sulawesi Utara. Untuk memperdalam penelitian ini dilakukan lewat wawancara dengan pegawai pemerintah daerah yang memiliki tugas pokok menarik pajak dan retribusi serta mendapatkan masukan dari akademisi dan masyarakat.

\section{Landasan Teori \\ Desentralisasi Fiskal}

Menurut Calsamiglia, Garcia-Milà, dan McGuire (2006: 1), terdapat argumen yang menentang desentralisasi fiskal dengan menyatakan bahwa sistem sentralisasi menghasilkan skala keekonomian dalam produksi barang publik dan mengakomodasi consumption spillovers lintas daerah, serta adanya kesulitan melakukan redistribusi pendapatan pada tingkat daerah bila menggunakan desentralisasi fiskal. Namun demikian, banyak pendapat yang mendukung desentralisasi fiskal dengan argumen masing-masing.

Xie, Zou, dan Davoodi (1999: 228) menyatakan bahwa desentralisasi fiskal, yaitu pelimpahan tanggung jawab fiskal pemerintah pusat kepada pemerintah daerah, dipandang sebagai sarana untuk meningkatkan efisensi pemerintah serta memperbesar pembangunan dan 
pertumbuhan ekonomi. Selanjutnya, Oates (1999) berargumentasi bahwa ada keuntungan efisiensi yang signifikan bila menerapkan desentralisasi fiskal dimana daerah diberikan wewenang fiskal. Khususnya, sistem desentralisasi dapat mengakomodasi permintaanpermintaan yang bervariasi atas barang publik lintas daerah. Adanya keuntungan yang dapat diperoleh lewat desentralisasi fiskal maupun kemauan politik, maka pada beberapa dekade terakhir banyak negara melakukan desentralisasi fiskal, termasuk Indonesia.

Pelimpahan wewenang fiskal kepada daerah memiliki empat hubungan keterkaitan utama, yaitu sebagai berikut (World Bank, 2003).

1. Keputusan-keputusan pengeluaran.

2. Kekuatan pemajakan dan memperoleh pendapatan.

3. Pinjaman daerah.

4. Transfer antar tingkatan pemerintahan.

\section{Model-Model Desentralisasi Fiskal}

Calsamiglia, Garcia-Milà, dan McGuire (2006: 7) mengemukakan adanya tiga sistem desentralisasi fiskal.

1. Sentralisasi penuh; dalam model ini pemerintah pusat mengenakan fungsi pajak yang seragam untuk memperoleh pendapatan yang diperuntukan bagi penyediaan barang publik yang sama lintas daerah. Transfer pemerintah pusat ke daerah merupakan satu-satunya sumber pembiayaan pengeluaran untuk barang publik di daerah. Pemerintah daerah hanya sekedar perpanjangan tangan pemerintah pusat untuk menangani pekerjaan administratif tanpa wewenang membuat keputusan.

2. Desentalisasi penuh; pada model ini pemerintah daerah memiliki wewenang pemajakan dan tanggung jawab meningkatkan PAD. Pemerintah daerah bebas menetapkan tingkat barang publik yang disediakan tanpa campur tangan ataupun bantuan dari pemerintah pusat. Mereka dapat memutuskan untuk membuat kontribusi sukarela kepada pemerintah daerah yang lain untuk membantu meningkatkan belanja untuk barang publik.

3. Tingkat minimum yang digaransi; model ini mengkombinasi beberapa atribut dari dua model di atas. Pemerintah pusat membebankan suatu sistem pajak yang sama untuk memperoleh pendapatan untuk membiayai transfer kepada pemerintah daerah yang mendukung suatu tingkatan minimal (mencukupi) dari barang publik di tiap daerah. Pemerintah daerah memiliki wewenang pajak lokal untuk mendapatkan pendapatan untuk menyesuaikan tingkat belanja di atas tingkat yang disyaratkan. Pemerintah daerah tidak memiliki wewenang untuk memberikan bantuan sukarela kepada pemerintah daerah yang lain.

Bila mengkaji penjelasan dari model-model di atas, desentralisasi di Indonesia menggunakan model yang ketiga, yaitu Tingkat Minimum yang Digaransi. Pemerintah pusat memberikan transfer untuk membiayai belanja barang publik minimum di daerah, sedangkan pemerintah daerah memiliki wewenang pajak lokal untuk belanja barang publik tambahan.

\section{Kemandirian Fiskal Daerah}

Kemandirian fiskal daerah atau kemandirian keuangan daerah merupakan prasyarat penting dalam pelaksanaan otonomi daerah melalui desentralisasinya. Suatu daerah dikatakan mampu untuk melaksanakan otonomi daerah salah satu cirinya terletak pada kemandirian keuangan daerah. Artinya, daerah otonom harus memiliki kewenangan dan kemampuan untuk 
menggali sumber-sumber keuangan sendiri, mengelola dan menggunakan keuangan sendiri yang cukup memadai untuk membiayai penyelenggaraan pemerintah daerah dan penyediaan barang publik.

Kemandirian fiskal dapat diukur melalui rasio kemandirian fiskal atau keuangan daerah. Rasio ini menggambarkan tingkat kemampuan suatu daerah dalam membiayai sendiri kegiatan pemerintahan, pembangunan dan pelayanan kepada masyarakat yang telah membayar pajak dan retribusi sebagai sumber pendapatan yang dibutuhkan daerah. Rasio kemandirian keuangan daerah diukur dengan membandingkan jumlah PAD dengan jumlah pendapatan daerah yang berasal dari sumber lain (eksternal), seperti Dana Alokasi Umum, Dana Alokasi Khusus, Bagi Hasil Pajak, bagi Hasil Sumber Daya Alam, Dana Darurat, dan Dana Pinjaman (Halim, 2001). Formula yang digunakan untuk menghitung Rasio Kemandirian adalah sebagai berikut.

$$
\text { Rasio Kemandiria } n \text { Keuangan Daerah }=\frac{\text { Pendapatan Asli Daerah }}{\text { Pendapatan dari Pihak Eksternal }}
$$

Rasio Kemandirian menggambarkan tingkat ketergantungan pemerintah daerah terhadap sumber dana eksternal. Semakin tinggi nilai rasio ini, semakin rendah tingkat ketergantungan suatu daerah terhadap sumber eksternal. Dengan kata lain, daerah tersebut semakin memiliki kemandirian fiskal, dan sebaliknya. Semakin tinggi rasio kemandirian berarti juga semakin tinggi partisipasi masyarakat dalam membayar pajak dan retribusi daerah.

\section{Sumber-Sumber Penerimaan Pemerintah Daerah di Indonesia}

Terdapat tiga kelompok besar sumber penerimaan pemerintah daerah, yaitu PAD, Dana Perimbangan, Pinjaman Daerah, dan Lain-Lain Pendapatan yang Sah. Menurut UU Nomor 33 Tahun 2004, PAD memuat beberapa rincian pendapatan, yaitu sebagai berikut.

1. Pajak daerah

2. Retribusi daerah

3. Hasil pengelolaan kekayaan daerah yang dipisahkan

4. Lain-lain PAD yang sah

Selanjutnya menurut UU tersebut, komponen dalam Lain-lain PAD yang Sah adalah sebagai berikut.

1. Hasil penjualan kekayaan Daerah yang tidak dipisahkan

2. Jasa giro

3. Pendapatan bunga

4. Keuntungan selisih nilai tukar rupiah terhadap mata uang asing

5. Komisi, potongan, ataupun bentuk lain sebagai akibat dari penjualan dan/atau pengadaan barang dan/atau jasa oleh daerah.

UU Nomor 33 Tahun 2004 juga mengatur mengenai dana perimbangan yang diberikan pemerintah pusat kepada pemerintah daerah yang mencakup berikut ini.

1. Dana bagi hasil yang terdiri dari dana bagi hasil pajak dan dana bagi hasil bukan pajak

2. Dana Alokasi Umum

3. Dana Alokasi Khusus

Pelaksanaan perimbangan keuangan antara pemerintah pusat dengan daerah bertujuan untuk mengatasi masalah kesenjangan antara pemerintah pusat dengan daerah (vertical imbalances) serta kesenjangan antar daerah (horizontal imbalances). 


\section{Pajak dan Retribusi Daerah}

Sifat pajak dan retribusi daerah adalah mutually exclusive, yaitu apabila suatu pajak atau retribusi daerah dipungut oleh provinsi, maka pemerintah kabupaten/kota tidak berhak memungut, dan sebaliknya. Pajak daerah adalah kontribusi wajib kepada daerah yang terutang oleh orang pribadi atau badan yang bersifat memaksa berdasarkan undang-undang, dengan tidak mendapatkan imbalan secara langsung dan digunakan untuk keperluan daerah bagi sebesarbesarnya kemakmuran rakyat. Di sisi lain, retribusi daerah merupakan pungutan daerah sebagai pembayaran atas jasa atau pemberian izin tertentu yang khusus disediakan dan/atau diberikan oleh pemerintah daerah untuk kepentingan orang pribadi atau badan (UU No. 28 Tahun 2009).

\section{Pajak dan Retribusi Daerah Pemerintah Kabupaten/Kota di Indonesia}

Pajak daerah yang dapat dipungut pemerintah kabupaten/kota di Indonesia sesuai UU Nomor 28 Tahun 2009 adalah: (1) pajak hotel; (2) pajak restoran; (3) pajak hiburan; (4) pajak reklame; (5) pajak penerangan jalan; (6) pajak mineral bukan logam dan batuan; (7) pajak parkir; (8) pajak air tanah; (9) pajak sarang burung wallet; (10) pajak bumi dan bangunan perdesaan dan perkotaan; dan (11) bea perolehan hak atas tanah dan bangunan.

Selanjutnya, retribusi daerah yang dapat dipungut pemerintah kabupaten/kota menurut undang-undang di atas adalah: (1) retribusi jasa umum dimana jenis retribusi ini dapat tidak dipungut apabila potensi penerimaannya kecil dan/atau atas kebijakan nasional/daerah untuk memberikan pelayanan tersebut secara cuma-cuma; (2) retribusi jasa usaha; dan (3) retribusi perizinan tertentu.

\section{Produk Domestik Regional Bruto (PDRB)}

PDRB merupakan salah satu indikator makro ekonomi yang pada umumnya digunakan untuk mengukur kinerja ekonomi di suatu daerah. PDRB dapat menggambarkan kemampuan suatu daerah mengelola sumber daya alam yang dimilikinya. Oleh karena itu besaran PDRB yang dihasilkan oleh masing-masing provinsi atau kabupaten/kota sangat bergantung kepada potensi sumber daya alam dan faktor produksi daerah. Adanya keterbatasan dalam penyediaan faktor-faktor tersebut menyebabkan besaran PDRB bervariasi antar daerah.

PDRB juga mencerminkan total nilai barang dan jasa yang diproduksi di wilayah (regional) tertentu dalam waktu tertentu. Cara perhitungan PDRB dapat diperoleh melalui tiga pendekatan, yaitu pendekatan produksi, pendekatan pendapatan dan pendekatan pengeluaran.

\section{Indeks Pembangunan Manusia (IPM)}

Tujuan utama dari penggunaan indikator IPM adalah meluaskan fokus perhatian tidak sekedar pendapatan masyarakat melainkan juga ukuran yang komprehensif atas pembangunan manusia. United Nations Development Programme (UNDP) tidak menyangkal bahwa pendapatan per kapita adalah salah satu penentu utama tingkat pembangunan manusia suatu negara, namun UNDP mengusulkan agar pendapatan sebagai hanya salah satu dari tiga faktor dalam mengukur pembangunan manusia, dimana dua lainnya adalah tingkat harapan hidup sebagai proksi untuk capaian kesehatan serta tingkat melek huruf bersama lama waktu sekolah sebagai proksi untuk capaian pendidikan. Ketiga indikator IPM diberikan bobot yang sama (Neumayer. 2001: 101). 


\section{Metode Penelitian}

Penelitian dilakukan pada seluruh kabupaten/kota di Sulawesi Utara untuk kurun waktu 2009-2012. Pemilihan kurun waktu tersebut didasarkan bahwa pada periode tersebut tidak terjadi pemekaran wilayah kabupaten/kota di Sulawesi Utara dan data yang dibutuhkan tersedia dengan lengkap. Untuk penelitian yang mendalam untuk mencari akar masalah dari temuan penelitian ini, maka dilakukan wawancara terhadap para pejabat yang terkait dengan pemungutan PAD. Untuk maksud tesebut metode sampling yang dilakukan adalah purposive judgement sampling. Pejabat yang diwawancara berasal dari tiga kota dan tiga kabupaten, yaitu Kota Bitung, Kota Manado, Kota Kotamobagu, Kabupaten Sangihe, dan Kabupaten Bolaang Mongondow Timur. Pemilihan daerah tersebut didasarkan pada pertimbangan kondisi daerah yang dapat merepresentasi kondisi kabupaten/kota yang ada di Sulawesi Utara.

Teknis analisis yang digunakan adalah Pooled EGLS (Cross-section random effects). Sehubungan digunakannya analisis data panel sebagai alat analisis, maka persamaan penelitian dikemukakan sebagai berikut.

$$
\begin{aligned}
& \operatorname{lnRKF} F_{\text {it }}=\alpha+\beta_{1} \operatorname{lnPDRB}_{\mathrm{it}}+\beta_{2} \operatorname{lnIPM}_{\mathrm{it}}+\beta_{3} \ln _{\mathrm{POP}}+\varepsilon \\
& \text { dimana } \\
& \text { RKF = Rasio Kemandirian Fiskal yang diukur melalui PAD dibagi pendapatan dari } \\
& \text { pihak eksternal } \\
& \text { PDRB }=\text { Produk domestik Regional Bruto } \\
& \text { IPM = Indeks Pembangunan Manusia } \\
& \text { POP = Jumlah populasi sebagai variabel kendali } \\
& \text { i } \quad=\text { kabupaten/kota } \\
& \mathrm{t} \quad=2008,2009, \ldots 2011
\end{aligned}
$$

\section{Perkembangan Perekonomian Kabupaten/Kota di Sulawesi Utara}

\section{Hasil Penelitian}

Perekonomian kabupaten/kota di Sulawesi Utara mengalami perkembangan dari tahun ke

\begin{tabular}{|c|c|c|c|c|c|}
\hline \multirow{2}{*}{ Kabupaten/Kota } & \multicolumn{5}{|c|}{ PDRB atas Dasar Harga Berlaku (Rp juta) } \\
\hline & 2008 & 2009 & 2010 & 2011 & 2012 \\
\hline Kabupaten Bolaang Mongondow & $1,522,626.22$ & $1,724,042.91$ & $1,957,551.97$ & $2,244,361,48$ & $2,484,291.87$ \\
\hline Kabupaten Minahasa & 3.341 .723 .28 & 3.811 .633 .95 & $4,337.830 .01$ & 4.862 .871 .90 & $5,416,621.22$ \\
\hline Kabupaten Sangihe & $1,062,205.69$ & $1,246,248.84$ & $1,473,073.28$ & $1,685,833.92$ & $1,876,787.83$ \\
\hline Kabupaten Talaud & $614,086.46$ & $682,563.38$ & $766,673.08$ & $883,880.82$ & $968,942.94$ \\
\hline Kabupaten Minahasa Selatan & $2,011,886.71$ & $2,278,367,41$ & $2,592,059.06$ & $3,005,034,33$ & $3,316,655,53$ \\
\hline Kabupaten Minahasa Utara & $2,063,203,26$ & $2,362,431.95$ & $2,660,389,29$ & $2,910,574,76$ & $3,228,425,74$ \\
\hline Kabupaten Bolaang Mongondow Utara & $550,050.87$ & $621,010.41$ & $707,123.63$ & 829.096 .88 & $934,724.48$ \\
\hline Kabupaten Sitaro & $431,435.72$ & $502,531.33$ & $592,916.48$ & $736,366.20$ & $858,515.63$ \\
\hline Kabupaten Minahasa Tenggara & $1,324,020.06$ & $1,520,400.71$ & $1,710,254.62$ & $1,977,026.09$ & $2,175,656.42$ \\
\hline Kabupaten Bolaang Mongondow Selatan & $355,546.30$ & $403,628.49$ & $465,671.99$ & $546,468.96$ & $616,291.59$ \\
\hline Kabupaten Bolaang Mongondow Timur & $561,910.24$ & $662,981.21$ & $767,649.30$ & $882,923.35$ & $977,350.10$ \\
\hline Kota Manado & $8,730,187,60$ & $10,487,596,56$ & $11,921,759,00$ & $13,446,834,30$ & $15,621,879,98$ \\
\hline Kota Bitung & $3,176,337,76$ & $3,508,907,43$ & $3,863,183.89$ & $4,232,420,19$ & $4,817,940,59$ \\
\hline Kota Tomohon & $1,097,831.50$ & $1,211,859.32$ & $1,325,191.87$ & $1,481,561.83$ & $1,637,616.57$ \\
\hline Kota Kotamobagu & $740,368.22$ & 859.069 .13 & $993,689.54$ & $1,124,717.22$ & $1,262,983.24$ \\
\hline
\end{tabular}
tahun. Namun demikian, masih terlihat kesenjangan pembangunan antara satu daerah dengan daerah lainnya, baik dari segi ukuran yang direpresentasikan oleh Produk Domestik Regional Bruto (PDRB) Harga Berlaku maupun tingkat pertumbuhannya. Pada Tabel 1 terlihat bahwa Kota Manado selalu memiliki PDRB Harga Berlaku yang terbesar. Pada tahun 2012, Kota Manado memiliki PDRB Harga Berlaku sebesar Rp 15,62 triliun. Nilai PDRB ini setara dengan 33,82 persen PDRB Sulawesi Utara pada tahun tersebut sebagaimana diperlihatkan pada Tabel 2.

Tabel 1 Perkembangan PDRB Berdasarkan Harga Berlaku Sulawesi Utara, 2008-2012

Sumber: Badan Pusat Statistik Sulawesi Utara 
Di sisi lain, Kabupaten Bolaang Mongondow Selatan memiliki PDRB Harga Berlaku terkecil di Sulawesi Utara. Pada tahun 2012, PDRB kabupaten tersebut sebesar Rp 616,29 miliar. Angka tersebut setara dengan 1,33 persen PDRB Provinsi Sulawesi Utara. Selanjutnya, Kota Bitung yang merupakan kota terbesar kedua di Sulawesi Utara hanya memiliki PDRB Harga Berlaku sebesar Rp 4,82 triliun atau kurang dari sepertiga PDRB Kota Manado yang merupakan ibukota provinsi. Mengingat Bitung merupakan kota pelabuhan terbesar di Sulawesi Utara dan juga merupakan salah satu pelabuhan terbesar di Kawasan Timur Indonesia, maka potensinya dapat ditingkatkan secara signifikan di masa mendatang.

Tabel 2 Kontribusi Tiap Kabupaten/Kota Terhadap Perekonomian Provinsi Sulawesi Utara, 2008-2012

\begin{tabular}{|c|c|c|c|c|c|}
\hline \multirow{2}{*}{ Kabupaten Kota } & \multicolumn{5}{|c|}{ Kontribusi Trap Kabussten Koba Terbadap Peralconomian Provinsi (9) } \\
\hline & 2008 & 2009 & 2010 & 2011 & 2012 \\
\hline Kabupaten Bolaang Mongondow & 5.52 & 5.41 & 5.42 & 5.49 & 5.38 \\
\hline Kabupaten Minahasa & 12.11 & 11.95 & 12.00 & 11.90 & 11.73 \\
\hline Kabupaten Sanghe & 3.85 & 3.91 & 4.08 & 4.13 & 4.06 \\
\hline Kabupaten Talaud & 2.23 & 2.14 & 2.12 & 2.16 & 2.10 \\
\hline Kabupaten Minahasa Selatan & 7.29 & 7.15 & 7.17 & 7.36 & 7.18 \\
\hline Kabupaten Minahasa Utara & 7.48 & 7.41 & 7.36 & 7.13 & 6.99 \\
\hline Kabupaten Bolaang Mongondow Utara & 1.99 & 1.95 & 1.96 & 2.03 & 2.02 \\
\hline Kabupaten Sitaro & 1.56 & 1.58 & 1.64 & 1.80 & 1.86 \\
\hline Kabupaten Minahasa Tenggara & 4.80 & 4.77 & 4.73 & 4.84 & 4.71 \\
\hline Kabupaten Bolaang Mongondow Selatan & 1.29 & 1.27 & 1.29 & 1.34 & 1.33 \\
\hline Kabupaten Bolaang Mongondow Tmur & 2.04 & 2.08 & 2.12 & 2.16 & 2.12 \\
\hline Kota Manado & 31.65 & 3289 & 32.99 & 32.92 & 33.82 \\
\hline Kota Bitung & 11.52 & 11.01 & 10.69 & 10.36 & 10.43 \\
\hline Kota Tomohon & 3.98 & 3.80 & 3.67 & 3.63 & 3.55 \\
\hline Kota Kotamobagu & 2.68 & 2.69 & 2.75 & 2.75 & 2.73 \\
\hline
\end{tabular}

Sumber: Badan Pusat Statistik Sulawesi Utara

Pertumbuhan ekonomi yang tinggi selalu dialami oleh Kota Manado sebagaimana diperlihatkan pada Tabel 3. Selama beberapa tahun terakhir perekonomian kota ini rata-rata tumbuh di atas angka 8 persen. Lebih lanjut, kabupaten/kota yang merupakan pemekaran Kabupaten Bolaang Mongondow awalnya memiliki pertumbuhan ekonomi yang rendah namun mengalami perbaikan signifikan pada beberapa tahun terakhir. Peningkatan pertumbuhan ekonomi yang terjadi di sana umumnya disebabkan pembangunan fasilitas pemerintah di kabupaten/kota yang baru tersebut sehingga dikhawatirkan akan mengalami penurunan pertumbuhan setelah selesainya pembangunan fasilitas pemerintah.

Perbaikan pertumbuhan ekonomi yang dinikmati kabupaten/kota di wilayah Bolaang Mongondow tidak ikut dinikmati oleh kabupaten-kabupaten kepulauan. Kabupaten Kepulauan Sangihe dan Kabupaten Kepulauan Talaud selalu tumbuh di bawah angka 6 persen. Akibatnya, kontribusi kedua kabupaten ini seperti terlihat pada Tabel 2 terus mengalami penurunan dari tahun ke tahun. Kondisi ini membutuhkan dukungan pemerintah untuk membangun fasilitas di pulau-pulau terpencil pada kedua kabupaten tersebut agar dapat mengurangi kesenjangan ekonomi dengan kabupaten/kota yang lain.

\section{Perkembangan Populasi Kabupaten/Kota di Sulawesi Utara}

Populasi Provinsi Sulawesi Utara pada tahun 2012 sebanyak 2.319.916 jiwa. Selama periode 2008-2012, populasi Sulawesi Utara bertambah rata-rata 1,24 persen per tahun. Angka ini menunjukan bahwa pertumbuhan populasi Sulawesi Utara relatif terkendali. Pertumbuhan 
populasi tersebut tidak sekedar berkaitan dengan jumlah kelahiran tetapi juga migrasi populasi dari provinsi lain ke Sulawesi Utara sebagai dampak dari pesatnya perkembangan ekonomi provinsi ini pada beberapa tahun terakhir.

Tabel 3 Pertumbuhan Ekonomi Sulawesi Utara, 2008-2012

\begin{tabular}{|c|c|c|c|c|c|c|}
\hline \multirow{2}{*}{ Provinsi/Kabupaten/Kota } & \multicolumn{6}{|c|}{ Pertumbuhan Ekonomi ( $\%)$} \\
\hline & 2008 & 2009 & 2010 & 2011 & 2012 & Rerata \\
\hline Provinsi Sulawesi Utara & 7.56 & 7.85 & 7.16 & 7.39 & 7.86 & 7.56 \\
\hline Kabupaten Bolaang Mongondow & 2.88 & 3.05 & 4.91 & 6.06 & 6.49 & 4.68 \\
\hline Kabupaten Minahasa & 5.37 & 5.92 & 6.24 & 6.35 & 6.81 & 6.14 \\
\hline Kabupaten Sangihe & 6.78 & 5.80 & 5.85 & 5.07 & 5.64 & 5.83 \\
\hline Kabupaten Talaud & 6.18 & 5.15 & 5.51 & 5.65 & 5.88 & 5.68 \\
\hline Kabupaten Minahasa Selatan & 7.75 & 6.41 & 8.57 & 6.03 & 6.37 & 7.03 \\
\hline Kabupaten Minahasa Utara & 7.71 & 6.86 & 7.27 & 6.93 & 7.01 & 7.16 \\
\hline Kabupaten Bolaang Mongondow Utara & 6.50 & 6.83 & 7.62 & 8.17 & 8.32 & 7.49 \\
\hline Kabupaten Sitaro & 8.19 & 7.18 & 7.36 & 7.54 & 8.32 & 7.72 \\
\hline Kabupaten Minahasa Tenggara & 6.90 & 5.66 & 8.09 & 5.60 & 6.43 & 6.54 \\
\hline Kabupaten Bolaang Mongondow Selatan & 5.80 & 6.05 & 6.82 & 7.72 & 8.09 & 6.89 \\
\hline Kabupaten Bolaang Mongondow Timur & 7.48 & 6.39 & 7.11 & 7.39 & 7.44 & 7.16 \\
\hline Kota Manado & 8.77 & 9.77 & 7.30 & 8.39 & 8.71 & 8.59 \\
\hline Kota Bitung & 6.76 & 6.13 & 6.88 & 7.76 & 7.98 & 7.10 \\
\hline Kota Tomohon & 8.96 & 6.09 & 6.10 & 6.36 & 7.10 & 6.92 \\
\hline Kota Kotamobagu & 9.36 & 7.88 & 7.42 & 7.05 & 7.55 & 7.85 \\
\hline
\end{tabular}

Sumber: Badan Pusat Statistik Sulawesi Utara

Populasi Sulawesi Utara terkonsentrasi di Kota Manado dan Kabupaten Minahasa. Pada tahun 2012 jumlah populasi di kedua daerah tersebut adalah 417.483 jiwa dan 316.884 jiwa, berturut-turut. Secara keseluruhan, penyebaran populasi di Sulawesi Utara belum merata. Pada tahun 2012, sebanyak 18,0 persen populasi Sulawesi Utara bertempat tinggal di Kota Manado walaupun luas wilayah Kota Manado hanya sebesar 1 persen dari total luas Sulawesi Utara. Ini disebabkan perekonomian Manado paling maju di Sulawesi Utara dan sangat pesat pertumbuhannya dibanding kabupaten/kota yang lain yang menarik masuknya pencari kerja ke kota tersebut. Selengkapnya dapat dilihat pada Tabel 4.

Perkembangan Kota Manado yang pesat tidak terlepas dari pembangunan kawasan bisnis dan infrastruktur penunjangnya, baik yang dilakukan swasta maupun pemerintah. Di sisi lain, Kabupaten Bolaang Mongondow Selatan merupakan daerah dengan jumlah populasi paling sedikit, yaitu 2,53 persen dari total populasi Sulawesi Utara walaupun memiliki wilayah yang cukup luas yaitu 12 persen dari total luas Sulawesi Utara. Kondisi ini seharusnya menjadi tantangan bagi kabupaten/kota dengan kepadatan populasi sangat rendah untuk menekan eksodus populasi mereka, lewat kegiatan pembangunan yang lebih serius di masing-masing daerah.

Tabel 4 Perkembangan Populasi Sulawesi Utara, 2008-2012

\begin{tabular}{|c|c|c|c|c|c|c|}
\hline \multirow{2}{*}{ No. } & \multirow{2}{*}{ Nama Kabupaten/Kota } & \multicolumn{5}{|c|}{ Jumlah Penduduk } \\
\hline & & 2008 & 2009 & 2010 & 2011 & 2012 \\
\hline \multicolumn{7}{|c|}{ Kabupaten } \\
\hline 1 & Bolaang Mongondow & 302,393 & 196,263 & 213,484 & 215,904 & 220,093 \\
\hline 2 & Minahasa & 298,179 & 300,226 & 310,384 & 313,892 & 316,884 \\
\hline 3 & Kepulauan Sangihe & 130,290 & 130,449 & 126,100 & 127,520 & 128,732 \\
\hline 4 & Kepulauan Talaud & 74,892 & 74,997 & 83,434 & 84,378 & 85,171 \\
\hline 5 & Minahasa Selatan & 182,292 & 182,818 & 195,553 & 197,755 & 198,901 \\
\hline 6 & Minahasa Utara & 174,455 & 176,480 & 188,904 & 191,036 & 193,906 \\
\hline 7 & Bolaang Mongondow Utara & 80,134 & 80,508 & 70,693 & 71,564 & 71,530 \\
\hline 8 & Kepulauan Sitaro & 61,652 & 61,781 & 63,801 & 64,516 & 64,575 \\
\hline 9 & Minahasa Tenggara & 95,145 & 95,525 & 100,443 & 101,575 & 101,761 \\
\hline 10 & Bolaang Mongondow Selatan & 51,537 & 52,122 & 57,001 & 57,648 & 58,762 \\
\hline 11 & Bolaang Mongondow Timur & 58,740 & 59,401 & 63,654 & 64,370 & 65,511 \\
\hline \multicolumn{7}{|c|}{ Kota } \\
\hline 12 & Manado & 429,149 & 434,845 & 410,481 & 415,114 & 417,483 \\
\hline 13 & Bitung & 178,266 & 180,618 & 187,652 & 189,920 & 193,956 \\
\hline 14 & Tomohon & 83,200 & 83,718 & 91,553 & 92,583 & 93,857 \\
\hline 15 & Kotamobaqu & 117,965 & 119,105 & 107,459 & 108,891 & 108,794 \\
\hline
\end{tabular}

Sumber: Badan Pusat Statistik Sulawesi Utara 


\section{Indeks Pembangunan Manusia Kabupaten/Kota di Sulawesi Utara}

Indeks Pembangunan Manusia (IPM) Sulawesi Utara tertinggi di Kawasan Timur Indonesia. Salah satu kelemahan mendasar dari pendapatan riil per kapita dalam mengukur kesejahteraan masyarakat adalah ketidakmampuan indikator tersebut mengadopsi pemerataan pendapatan antar masyarakat. Oleh sebab itu, IPM sering digunakan sebagai indikator pelengkap untuk mengukur kesejahteraan. Kinerja Sulawesi Utara untuk indikator ini sangat baik dimana provinsi ini memiliki IPM tertinggi di Kawasan Timur Indonesia, yaitu sebesar 76,95 dan menduduki ranking II nasional hingga tahun 2012. Hal ini mengindikasikan bahwa kesejahteraan populasi semakin baik sehingga anggota masyarakat dapat memenuhi berbagai standar hidup yang menjadi komponen IPM secara lebih baik.

Pada tingkatan kabupaten/kota, Manado memiliki IPM tertinggi pada tahun 2012 yaitu memiliki nilai 78,92 persen dan diikuti oleh Kota Tomohon dengan nilai 77,40. Namun demikian, masih terdapat ketimpangan IPM antar kabupaten/kota di Sulawesi Utara. Beberapa kabupaten masih memiliki nilai yang rendah, yaitu di bawah 74 persen, bahkan Kabupaten Bolaang Mongondow Selatan hanya memiliki nilai 71,63 persen. Tabel 5 memperlihatkan perkembangan IPM di Sulawesi Utara.

Tabel 5 Perkembangan Indeks Pembangunan Manusia Sulawesi Utara, 2008-2012

\begin{tabular}{|c|c|c|c|c|c|}
\hline \multirow{2}{*}{ Provinsi/Kabupaten.Kota } & \multicolumn{5}{|c|}{ Tahun } \\
\hline & 2008 & 2009 & 2010 & 2011 & 2012 \\
\hline SULAWESI UTARA & 75.16 & 75.68 & 76.09 & 76.51 & 76.95 \\
\hline Kabupaten Bolaang Mongondow & 72.11 & 72.52 & 72.99 & 73.39 & 73.83 \\
\hline Kabupaten Minahasa & 74.86 & 75.28 & 75.74 & 76.07 & 76.69 \\
\hline Kabupaten Sangihe & 74.67 & 75.21 & 75.58 & 75.99 & 76.42 \\
\hline Kabupaten Talaud & 74.34 & 74.83 & 75.30 & 75.70 & 76.14 \\
\hline Kabupaten Minahasa Selatan & 73.79 & 74.18 & 74.68 & 75.01 & 75.46 \\
\hline Kabupaten Minahasa Utara & 75.33 & 75.57 & 76.08 & 76.45 & 76.91 \\
\hline Kabupaten Bolaang Mongondow Utara & 71.84 & 72.27 & 72.63 & 73.06 & 73.48 \\
\hline Kabupaten Minahasa Tenggara & 71.87 & 72.31 & 72.71 & 73.07 & 73.42 \\
\hline Kabupaten Sitaro & 72.58 & 72.86 & 73.30 & 73.66 & 74.06 \\
\hline Kabupaten Bolaang Mongondow Selatan & 69.65 & 70.03 & 70.36 & 71.09 & 71.63 \\
\hline Kabupaten Bolaang Mongondow Timur & 71.49 & 71.85 & 72.27 & 72.86 & 73.41 \\
\hline Kota Manado & 77.28 & 77.79 & 78.02 & 78.55 & 78.92 \\
\hline Kota Bitung & 74.61 & 75.00 & 75.52 & 75.91 & 76.30 \\
\hline Kota Tomohon & 75.65 & 76.09 & 76.39 & 76.87 & 77.40 \\
\hline Kota Kotamobago & 74.46 & 75.03 & 75.53 & 75.98 & 76.68 \\
\hline
\end{tabular}

Sumber: Badan Pusat Statistik Sulawesi Utara

\section{Pendapatan Pemerintah Kabupaten/Kota di Sulawesi Utara}

Pada tahun 2009, pendapatan keseluruhan pemerintah kabupaten kota di Sulawesi Utara sebesar Rp 5,46 triliun. Angka tersebut meningkat menjadi Rp 7,36 triliun pada tahun 2012 atau meningkat rata-rata 10,42 persen per tahun untuk kurun waktu tersebut. Kenaikan terutama berasal dari dana eksternal, yaitu dari pemerintah pusat dan provinsi.

Pada Tabel 6 terlihat bahwa peran Pendapatan Asli Daerah (PAD) terhadap pendapatan pemerintah kabupaten/kota di Sulawesi Utara masih sangat terbatas. PAD Kota Manado yang merupakan ibukota provinsi baru mencapai 17,18 persen dari total pendapatannya pada tahun 2012. Kontribusi PAD dari kabupaten/kota lainnya pada tahun yang sama sangat kecil, yaitu rata-rata 3,41 persen. Ini mengindikasikan bahwa tingkat kemandirian fiskal kabupaten/kota di Sulawesi Utara relatif masih rendah sehingga hubungannya dengan pemerintah pusat dan provinsi bersifat Instruktif. Selengkapnya diperlihatkan pada Tabel 6 . 


\section{Hasil Analisis Statistik}

Tabel 7 memperlihatkan hasil analisis panel dengan menggunakan metode Pooled EGLS (Cross-section random effects) atas data yang digunakan. Hasil pada tabel tersebut memperlihatkan bahwa perkembangan perekonomian kabupaten/kota di Sulawesi Utara yang diproksi oleh PDRB tidak berpengaruh signifikan terhadap kemandirian fiskal pemerintah kabupaten/kota di Sulawesi Utara. Kondisi ini disebabkan oleh beberapa faktor di antaranya sebagai berikut.

Tabel 6 Pendapatan Total Pendapatan dan PAD Pemerintah Di Sulawesi Utara, 2009-2012

\begin{tabular}{|c|c|c|c|c|c|c|c|c|c|}
\hline \multirow{2}{*}{ 1ha. } & \multirow{2}{*}{ Hana KotupienKKas } & \multicolumn{2}{|c|}{2119} & \multicolumn{2}{|r|}{298} & \multicolumn{2}{|c|}{2111} & \multicolumn{2}{|c|}{21212} \\
\hline & & $P A D$ & Tetal & 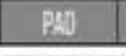 & Totil & $P 20$ & Total & PAD & Totel \\
\hline & 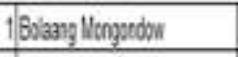 & $7987,010,952$ & 423.299 .222002 & 5948,0860264 & $43.73,165.923$ & 19,124,705,112 & $496256.72,838$ & 162768666870 & $586611,000,000$ \\
\hline & 2lltrahssa & 23746299997 & $575,407,71606$ & $24.601,935,542$ & $593,219,470,497$ & 238090.653 .36 & 66424,041274 & $22,47,366,44$ & $713.551,000000$ \\
\hline & Kapdia:an Sarghte & 244602953 & 488, 37, , 1E4, 639 & $23,768,36,702$ & 41,100642787 & $28.5660 .013,461$ & $566,133,424.42$ & $27,50.410,58$ & 52887,000020 \\
\hline & 4 Kapulasan Talant & $401.198,150$ & 375.551399 .163 & 769.485, 127 & 356.604 .747 .800 & 87755980.982 & $398,62,576,507$ & $10,5008553.378$ & $465.34 .017,25$ \\
\hline & SMrahasa Seltaten & 5724776656 & $422559,956,179$ & $5,54.259278$ & $412+28217,730$ & 9407720.04 & $515,891,262257$ & $10,620007,45$ & 52830100000 \\
\hline & 6) Horahssa Utare & $11,755.699676$ & $396,107,015,339$ & $10522,025,555$ & $335.84224,597$ & 15,720449207 & $400709,609,721$ & 25,20097279 & 512822,0000000 \\
\hline & 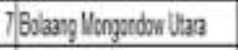 & 4996005252 & $328,174828,28$ & 9090, (42 60): & $346,751,026,676$ & $69,19,465,320$ & 395,662282811 & $6,609,727,72$ & 336203,000000 \\
\hline & 8) Kapdizan Sian & $8.47,001,975$ & $327,800,730450$ & $12.007,488,47$ & $351,023,3722$ & $13703,256,396$ & $45248,715, \mathrm{mot}$ & 13.32 .0215 .56 & 30,80000000 \\
\hline & SHrahtsat Tenzogara & 254,791,030 & $366,35,742,532$ & $4,50,161,73:$ & $348,377,017,23$ & 4955574,22 & 410033,600571 & 4.24.0035.582 & 362955,0000000 \\
\hline & 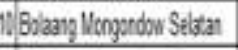 & 858691,776 & $78734,578,969$ & 2575,64253 & $273,837,739,000$ & 4784.044 .866 & 331994368387 & $7,033,702128$ & $287.055,0000000$ \\
\hline & 11 Bvazyg Vtangyodow Tmy & 41479662 & 74.3505028 & 2871200733 & $287,59804.04 .563$ & $6,498.81,1057$ & $335,355909,796$ & 9.309 .96678 & 26331,000000 \\
\hline & 24llanado & 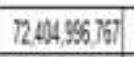 & $647,169850.6969$ & $90,82,486.995$ & 672.5018053 .401 & $134,72,120,42$ & 699.152 .5568566 & 1783707000000 & $1,037,500,000,000$ \\
\hline & 13 Giang & $16,82,773,84$ & $477,699954,976$ & $18.763,528.51$ & $45,819,338,44$ & $25,394,053,797$ & $400,036,27,653$ & $36,45,120,912$ & $555,50,000000$ \\
\hline & 14 Tenchos & $6392,461,1,22$ & $324,620,805,578$ & 57793,312955 & $345,40255,400$ & $8055,020.62$ & $363,04240,45$ & $11,24,655,125$ & 388662,0000000 \\
\hline & 15) Kotancbays & $6,122,46220$ & 338,309576653 & 8.57, $737,32$. & $373,056,727,180$ & 9394639,155 & $398887,650,348$ & $11,100,179,80$ & $366530,000,028$ \\
\hline
\end{tabular}

Sumber: Direktorat Jenderal Perimbangan Keuangan Kementerian Keuangan

1. PDRB kabupaten/kota di luar Manado dan Bitung didominasi oleh sektor Pertanian. Kegiatan dalam sektor ini sebagian besar bukan merupakan objek pajak dan retribusi daerah. Beberapa kabupaten/kota mencoba menarik retribusi atas hasil pertanian dan perikanan namun mendapat tantangan, terutama dengan pertimbangan bahwa beban akhirnya (economic incidence) akan ditanggung oleh petani dan nelayan miskin.

2. Jenis pajak daerah di Indonesia yang berupa Daftar Tertutup (Closed List) memberikan dasar pajak (tax base) yang sangat bervariasi antara kabupaten/kota yang memiliki kota besar dan kecil. Kota yang relatif besar umumnya memiliki tax base yang besar untuk kegiatan parkir, perhotelan, restoran, dan perizinan. Sebaliknya daerah kecil kebanyakan bertumpu pada Pajak Galian C yang berupa pajak atas penambangan batu dan pasir. Pajak daerah ini secara lingkungan menjadi perhatian serius mengingat dampak negatif bagi lingkungan yang cukup besar dari kegiatan yang menjadi objek pajak. Para ahli lingkungan memperkirakan pendapatan pajak dari kegiatan ini tidak mampu mengkompensasi bencana lingkungan seandainya terjadi. 
Tabel 7 Hasil Analisis atas Faktor yang Mempengaruhi Kemandirian Fiskal Pemerintah Kabupaten/Kota Di Sulawesi Utara

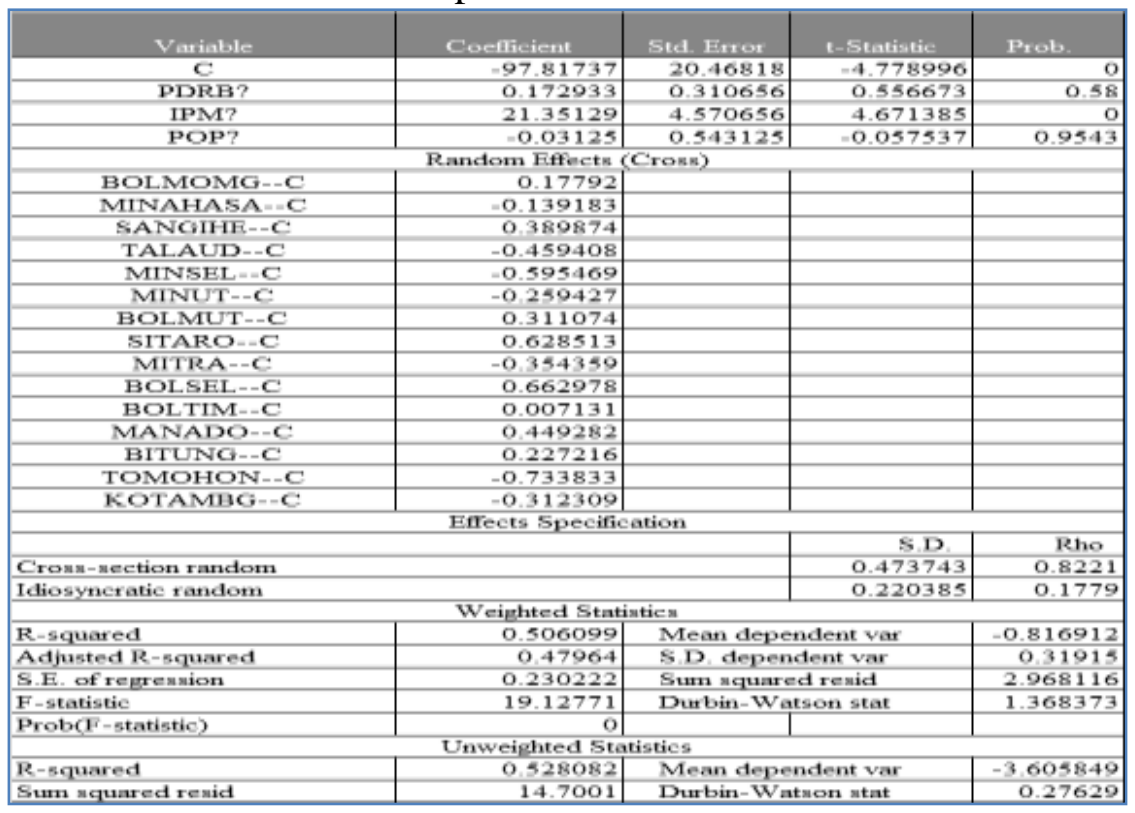

Sumber : Data olahan

3. Minimnya upaya petugas yang bertanggung jawab memungut pajak untuk melakukan intensifikasi dan ekstensifikasi pajak dan retribusi daerah secara kreatif. Ini dipengaruhi juga oleh perilaku petugas untuk tidak meningkatkan pendapatan pajak dan retribusi daerah secara signifikan dalam rangka mencegah penetapan target yang jauh lebih tinggi untuk tahun anggaran berikutnya.

4. Rendahnya upaya untuk melakukan pengawasan terhadap pemungutan pajak dan retribusi daerah sehingga terjadi kebocoran penerimaan.

5. Masih rendahnya kesadaran wajib pajak dan retribusi daerah untuk menjalankan kewajibannya. Salah satu penyebabnya adalah mereka merasakan kurangnya pelayanan pemerintah daerah.

Penelitian ini juga memperlihatkan adanya pengaruh positif dan signifikan dari Indeks Pembangunan Manusia (IPM) terhadap kemandirian fiskal pemerintah daerah di Sulawesi Utara. Hasil ini sejalan dengan pandangan umum yaitu membaiknya kualitas SDM di daerah akan memberikan peluang lebih besar bagi mereka untuk mendapatkan pekerjaan atau membuka lapangan pekerjaan. Dengan demikian peluang untuk memperoleh PAD semakin besar.

Akhirnya penelitian ini memperlihatkan bahwa perkembangan populasi tidak berpengaruh secara signifikan terhadap kemandirian fiskal pemerintah kabupaten/kota di Sulawesi Utara. Faktor penyebab kondisi tersebut diantaranya adalah Tingkat Pengangguran dan Angka Kemiskinan di kabupaten/kota di Sulawesi Utara masih relatif tinggi. Pada tahun penelitian, tingkat pengangguran dan angka kemiskinan masih di atas 7 persen. Perkembangan populasi sesungguhnya memberi peluang meningkatkan PAD. Namun demikian, tingginya pengangguran dan kemiskinan membuat perkembangan populasi menjadi kurang bermanfaat untuk peningkatan $\mathrm{PAD}$, bahkan cenderung menjadi beban pemerintah. 


\section{Beberapa Faktor yang Kurang Mendukung Kemandirian Fiskal}

Penelitian yang mendalam atas kemandirian fiskal yang diperoleh lewat wawancara dengan pejabat di instansi yang memiliki tugas pokok menghasilkan PAD serta lewat focus group discussion (FGD) memperlihatkan beberapa faktor yang menyebabkan rendahnya kemandirian fiscal pada kabupaten/kota di Sulawesi Utara.

1. Hampir semua pajak daerah memiliki tax base yang sangat sempit pada kebanyakan kabupaten/kota di Sulawesi Utara.

2. SDM pada SKPD yang memiliki tugas pokok utama mencari pendapatan memiliki jumlah yang terbatas. Di samping itu, jumlah petugas penagih dan pengawas umumnya lebih sedikit dibanding petugas yang melakukan kegiatan administrasi.

3. Rendahnya pengawasan dalam pemungutan pajak dan retribusi.

4. Masih rendahnya upaya pemerintah kabupaten/kota untuk melakukan pemungutan pajak, baik intensifikasi maupun ekstensifikasi. Terdapat kecenderungan, perhatian lebih banyak diberikan kepada subjek maupun objek pajak yang ada. Apabila ada kenaikan target, maka subjek dan wajib pajak daerahyang ada akan mendapat tekanan meningkatkan setoran. Dalam hal ini membagi beban antara anggota masyarakat belum menjadi perhatian serius. Hal ini melanggar prinsip keadilan dalam perpajakan.

\section{Kesimpulan}

Hasil penelitian mengenai kemandirian fiskal kabupaten/kota di Sulawesi Utara dapat disimpulkan sebagai berikut.

1. Perkembangan perekonomian kabupaten/kota di Sulawesi Utara tidak berpengaruh signifikan terhadap kemandirian fiskal pemerintah kabupaten/kota di Sulawesi Utara. Ini disebabkan oleh beberapa faktor diantaranya: (1) sektor yang mendominasi perekonomian kabupaten/kota di luar Manado dan Bitung adalah sektor Pertanian yang kegiatannya sebagian besar bukan merupakan objek pajak dan retribusi daerah; (2) jenis pajak daerah yang diizinkan Pemerintah Pusat memiliki dasar pajak (tax base) yang sangat kecil pada kabupaten/kota di Sulawesi Utara; (3) minimnya upaya melakukan intensifikasi dan ekstensifikasi pajak dan retribusi daerah secara kreatif yang salah satunya dipengaruhi oleh perilaku petugas yang tidak meningkatkan pendapatan pajak dan retribusi secara signifikan dalam rangka mencegah penetapan target yang jauh lebih tinggi untuk tahun anggaran berikutnya; (3) rendahnya upaya untuk melakukan pengawasan terhadap pemungutan pajak dan retribusi daerah sehingga terjadi kebocoran penerimaan; dan (4) masih rendahnya kesadaran wajib pajak dan retribusi daerah untuk menjalankan kewajibannya. Salah satu penyebabnya adalah mereka merasakan kurangnya pelayanan pemerintah daerah.

2. Indeks Pembangunan Manusia (IPM) memiliki pengaruh yang positif dan signifikan terhadap kemandirian fiskal pemerintah kabupaten/kota di Sulawesi Utara. Ini sejalan dengan pandangan umum yaitu membaiknya kualitas SDM di daerah akan memberikan peluang lebih besar bagi mereka untuk mendapatkan pekerjaan atau membuka lapangan pekerjaan.

3. Perkembangan populasi tidak berpengaruh secara signifikan terhadap kemandirian fiskal pemerintah kabupaten/kota di Sulawesi Utara. Faktor penyebab kondisi tersebut diantaranya adalah Tingkat Pengangguran dan Angka Kemiskinan di kabupaten/kota di Sulawesi Utara masih relatif tinggi. Perkembangan populasi sesungguhnya memberi peluang meningkatkan PAD. Namun tingginya pengangguran dan kemiskinan membuat 
perkembangan populasi menjadi kurang bermanfaat untuk peningkatan PAD, bahkan cenderung menjadi beban pemerintah.

4. Pelimpahan Pajak Bumi dan Bangunan Perkotaan dan Pedesaan (PBB-P2) menjadi pajak daerah dirasakan sangat merugikan kabupaten/kota di Sulawesi Utara. Di satu sisi, pelimpahan PBB-P2 akan menambah beban pemerintah daerah dan di sisi lain akan mengurangi pendapatan pemerintah daerah di Sulawesi Utara karena tidak lagi menerima Dana Ekualisasi atau subsidi silang yang berasal dari kota-kota besar di Indonesia terkait dengan PBB-P2. Selain itu, pada saat penyerahan data PBB-P2 dari Kantor Pelayanan Pajak (KPP) kepada pemerintah kabupaten/kota terdapat dua permasalahan mendasar yang muncul. Pertama, banyak objek PBB-P2 tidak terdata pada KPP. Dengan demikian, banyak potensi PBB-P2 yang hilang selama ini. Kedua, banyak wajib pajak PBB-P2 telah membayar kewajibannya pada tahun-tahun sebelumnya, namun tidak ada catatan pelunasannya sehingga pihak kebupaten/kota menagih kembali.

5. Kemandirian fiskal yang masih sangat rendah pada kabupaten/kota di Sulawesi Utara merupakan akibat dari: (1) hampir semua pajak daerah memiliki tax base yang sangat sempit pada kebanyakan kabupaten/kota di Sulawesi Utara; (2) SDM pada SKPD yang memiliki tugas pokok utama mencari pendapatan memiliki jumlah yang terbatas. Di samping itu, petugas penagih dan pengawas umumnya lebih sedikit dibanding petugas yang melakukan kegiatan administrasi; (3) rendahnya pengawasan dalam pemungutan pajak dan retribusi; dan (4) masih rendahnya upaya pemerintah kabupaten/kota untuk melakukan pemungutan pajak, baik intensifikasi maupun ekstensifikasi. Terdapat kecenderungan, perhatian lebih banyak diberikan kepada subjek maupun objek pajak yang ada.

\section{Saran} berikut ini.

Berdasarkan temuan dalam penelitian ini, maka dapat diberikan saran sebagaimana

1. Jumlah petugas pada instansi yang tugas pokoknya menghasilkan PAD relatif masih sedikit dibandingkan dengan tanggung jawab yang diberikan. Selain itu perlu diperhatikan komposisi tenaga teknis dan tenaga administrasi pada instansi tersebut dimana komposisi tenaga teknis seharusnya lebih besar dari tenaga administrasi.

2. Hasil penelitian memperlihatkan bahwa SDM dalam bidang perpajakan dan retribusi daerah secara rata-rata masih relatif rendah bila dikaitkan dengan bidang tugas masing-masing. Oleh sebab itu, dibutuhkan pelatihan efektif yang berhubungan dengan upaya peningkatan PAD.

3. Tarif dan cakupan pajak pajak daerah untuk kegiatan produktif pada sebagian besar pemerintah kabupaten/kota di Sulawesi Utara masih relatif rendah. Ini membutuhkan revisi Peraturan Daerah tentang Pajak dan Retribusi Daerah.

4. Pelimpahan PBB-P2 menjadi Pajak Daerah memiliki masalah mengenai data objek pajak. Ini membutuhkan upaya pendataan kembali oleh pemerintah kabupaten/kota terhadap objek dari pajak tersebut.

5. Penelitian ini masih terbatas pada kemandirian fiskal kabupaten/kota di Sulawesi Utara. Ke depan, penelitian dapat dilanjutkan ke provinsi lain di Sulawesi dan provinsi di luar Sulawesi untuk menangkap fenomena kemandirian fiskal di Indonesia serta dapat dikomparasi berdasarkan wilayah. 


\section{DAFTAR PUSTAKA}

Bahl, R. (1999), “Implementation Rules For Fiscal Decentralization,” Working Paper 99-1 Andrew Young School of Policy Studies Georgia State University, Atlanta.

Calsamiglia, Xavier (2006), "Why do Differences in the Degree of Fiskal Decentralization Endure?" http://www.ifigr.org/workshop/IFIR-CESifo/papers/mcguire.pdf

Halim, A. (2001). Akuntansi Keuangan Daerah. Penerbit Salemba Empat, Jakarta

Hidayat, Afri (2009), "Analisis Pengaruh Pertumbuhan Ekonomi terhadap PAD Provinsi Sumatera Utara," Fakultas Ekonomi Universitas Sumatera Utara

Ibarra, Jorge, Salazar Raymundo Rodríguez, dan Guajardo (2009), "Fiscal Coordination and Financial Dependence of State Governments in Mexico," Working Paper Nomor 43 Department of Economics Tecnológico de Monterrey.

Lovell, C. (1981), "Evolving Local Government Dependency," Public Administration Review, 41: $189-202$.

Mardiasmo (2002), Otonomi Dan Manajemen Keuangan Daerah, Penerbit Andi Offset, Yogyakarta.

Musgrave, R.A. (1983), Who Should Tax, Where and What? In Tax Assignment in Federal Countries, Edited by Charles McLure, Jr., Canberra: Center of Research on Federal Financial Relations, Australian National University.

Neumayer, Eric (2001), "The Human Development Index and Sustainability - A Constructive Proposal, "Ecological Economics, 39: 101-114.

Oates, W.(1993), "Fiscal Decentralization And Economic Development," National Tax Journal, XLVI: 237-243.

------ (1999), “An Essay on Fiskal Federalism,” Journal of Economic Literature, XXXVII: $1120-1149$

------- (2005), "Toward A Second-Generation Theory of Fiscal Federalism," International Tax and Public Finance, 12: 349-373.

Utami, Ayu Mita (2012), "Pengaruh Investasi dan Pertumbuhan Ekonomi terhadap Pendapatan Asli Daerah ( Studi Kasus di Pemerintahan Kota Tasikmalaya )," Fakultas Ekonomi Universitas Siliwangi.

World Bank (2003), "The Economics of Fiscal Decentralisation: Framework and Principles," http://www.worldbank.org;

Xie, Danyang, Heng-fu Zou, dan Hamid Davoodi (1999), "Fiscal Decentralization and Economic Growth in the United States," Journal of Urban Economics, 45:228-239 